\title{
Phosphatidylinositol 3-kinase/Akt regulates the balance between plasminogen activator inhibitor-1 and urokinase to promote migration of SKOV-3 ovarian cancer cells
}

\author{
Brandi R. Whitley ${ }^{\mathrm{a}, 1}$, Lea M. Beaulieu ${ }^{\mathrm{a}}$, Jennifer C. Carter ${ }^{\mathrm{a}}$, and Frank C. Church ${ }^{\mathrm{a}, \mathrm{b}, \mathrm{c},{ }^{*}}$ \\ aDepartments of Pathology and Laboratory Medicine, The University of North Carolina at Chapel \\ Hill School of Medicine, Chapel Hill, NC 27599-7035, USA \\ bDepartment of Pharmacology, The University of North Carolina at Chapel Hill School of \\ Medicine, Chapel Hill, NC 27599-7035, USA \\ 'Department Medicine, The University of North Carolina at Chapel Hill School of Medicine, \\ Chapel Hill, NC 27599-7035, USA
}

\begin{abstract}
Objectives-Increased levels of urokinase-type plasminogen activator (uPA) are associated with shortened overall survival in ovarian cancer patients. Additionally, elevated levels of the serine protease inhibitor (serpin), plasminogen activator inhibitor-1 (PAI-1), a uPA inhibitor, have also been correlated with an unfavorable prognosis in ovarian cancer. Therefore, it is critical to understand the signaling pathways that regulate PAI-1 and uPA expression in cancer cell migration-invasion.
\end{abstract}

\begin{abstract}
Methods-We studied the PI3K/Akt, Rho kinase/ROCK, p38 MAPK and MEK pathways and their modulation of PAI-1 and uPA expression and wound-induced cell migration in SKOV-3 ovarian cancer cells. The PI3K/Akt pathway was further examined using pharmacological inhibitors (LY294002 and wortmannin), Akt siRNA, constitutively active Akt adenovirus and treatment with IGF-1/insulin in the SKOV-3 cells.
\end{abstract}

Results-The PI3K/Akt pathway negatively regulates PAI-1 expression and positively correlates with migratory abilities and uPA expression in SKOV-3 cells. A reduction in active Akt results in an increase in PAI-1 expression coupled with a decrease in UPA expression to ultimately result in reduced cell migration and invasion. By contrast, an increase in Akt activity reduces PAI-1 expression and results in an increase in SKOV-3 wound-induced cell migration. Furthermore, IGF-1 and insulin stimulated SKOV-3 migration by altering the balance between uPA and PAI-1 to favor uPA, and the enhanced migration was attenuated by treatment with LY294002 indicating $\mathrm{PI} 3 \mathrm{~K} / \mathrm{Akt}$ in this pathway.

\footnotetext{
(C) 2006 Elsevier Inc. All rights reserved.

*Corresponding author. Division of Hematology-Oncology/Department of Medicine, 932 Mary Ellen Jones Bldg., Campus Box 7035, University of North Carolina at Chapel Hill, School of Medicine, Chapel Hill, NC 27599-7035, USA. Fax: +1 9199667639. fchurch@email.unc.edu (F.C. Church).

${ }^{1}$ Current affiliation: Cato Research Inc., Durham, NC 27713, USA.
} 
Conclusions-These results suggest an overall ovarian tumor-protective role for PAI-1, and that the PI3K/Akt signaling pathway regulates the ratio of PAI-1:uPA to either increase or decrease cell migration.

\section{Keywords}

Plasminogen activator system; PAI-1; Urokinase; Migration and invasion; SKOV-3 cells; PI3K/Akt signaling system

\section{Introduction}

Ovarian cancer accounts for $4 \%$ of all cancers among women but it is the leading cause of gynecological cancer deaths [1]. Advanced ovarian cancer is characterized by a high frequency of metastasis to lymph nodes and invasive growth into multiple organs due to peritoneal dissemination [2,3]. Invasive ovarian cancers demonstrate increased levels of the serine protease, urokinase-type plasminogen activator (uPA), and its serine protease inhibitor (serpin), plasminogen activator inhibitor-1 (PAI-1), compared with benign ovarian cancer or normal ovary. These increased amounts of uPA and PAI- 1 are typically correlated with a more aggressive phenotype of ovarian cancer and are linked to a poor prognosis [48]. Upon binding its cell surface urokinase receptor (UPAR), uPA activates plasminogen into plasmin to facilitate extracellular matrix degradation and tumor cell invasion. In addition to proteolytic activity and regulation, uPA, PAI-1 and uPAR are implicated in cell signaling pathways controlling cell proliferation, migration and invasion.

The PI3K/Akt cell signaling pathway is implicated in cell migration and invasion [9-11]. The PI3K/Akt pathway regulates uPA expression; selective inhibition of the PI3K/Akt pathway in numerous cell types decreases uPA expression and/ or activity with a subsequent decrease in cell invasion [12-14]. Urokinase itself has been reported to stimulate PI3K activity and activates the downstream effectors Akt [15,16] and Rac1 [17]. Inversely, antisense UPA in glioblastoma cells causes a decrease both in wound migration and in PI3K/Akt activity [18]. Conversely, looking at PAI-1 levels, both hypoxia-induced PAI-1 expression [19] and nerve growth factor-induced PAI-1 expression [20] can be inhibited by PI3K inhibitors. A link between PAI-1 and phosphorylated Akt was recently demonstrated in aortic endothelial cells from the PAI-1 knockout mouse, which showed increased phosphorylated Akt levels compared to wild-type aortic endothelial cells [21]. Furthermore, both insulin-like growth factor-1 (IGF-1) and insulin modulate expression of uPA and PAI-1 through PI3K/Akt in breast cancer cells and in adipocytes [22,23]. IGF-1 and insulin are involved in cell survival, proliferation and cell migration; thus, their interaction with PI3K/Akt and the changes in expression of uPA and PAI-1 are being studied in many different disease settings.

The PI3K pathway is important in ovarian carcinogenesis [24]. Akt has been shown to be amplified or over-expressed in ovarian cancer, implying that it also has a role in ovarian carcinogenesis [25-28]. PI3K is constitutively activated in the SKOV-3 ovarian cancer cell line [27]. The PI3K/Akt pathway is an important signaling pathway to examine in the context of ovarian cancer and in relation to both PAI-1 and uPA expression. Using the SKOV-3 ovarian cancer cell line as a model for ovarian cancer in in vitro migration assays, 
we sought to better understand the relationship of the PI3K/Akt pathway to PAI-1 and uPA. This study describes the effects of a selection of signaling pathway inhibitors on both basal unstimulated SKOV-3 and on insulin- and IGF-1-treated SKOV-3 cell migration.

\section{Materials and methods}

\section{Cell Culture}

SKOV-3 cells were obtained from the University of North Carolina Tissue Culture Facility in the Lineberger Comprehensive Cancer Center and maintained as monolayer culture in minimal Dulbecco's modified Eagle's medium (DMEM) supplemented with 10\% fetal bovine serum (FBS) and 1\% antibiotic/antimycotic in a humidified chamber with $5 \% \mathrm{CO}_{2}$ at $37^{\circ} \mathrm{C}$.

\section{Wound-induced migration assay}

Confluent SKOV-3 monolayers were scratched with a sterile yellow pipette tip, washed and then treated with serum-free media containing the given concentrations of signal pathway inhibitors (Y27632 and SB203580 were obtained from Calbiochem, San Diego, CA; LY294002, wortmannin and PD98059 were from Biomol, Plymouth Meeting, PA) and/or blocking antibodies (PAI-1 or uPA antibody, both from American Diagnostica, Stamford, CT).Wound-induced migration assays with Akt siRNA or Akt adenovirus-treated SKOV-3 cells were performed in 1\% FBS-containing media. Additional wound-induced migration assays with IGF-1 and insulin were performed on serum-starved SKOV-3 monolayers, as described previously [29]. Cells were pre-treated for $1 \mathrm{~h}$ with sterile DMSO (Sigma, St. Louis, MO) or $50 \mu \mathrm{MLY} 294002$ in serum-free media, scratched, washed and then treated with $100 \mathrm{nM}$ insulin (Invitrogen, Carlsbad, CA) or $50 \mathrm{ng} / \mathrm{mL}$ IGF-1 (R\&D Systems, Minneapolis, MN) in the absence or presence of $50 \mu \mathrm{M}$ LY294002 in serum-free media for $24 \mathrm{~h}$.

Migration of cells into the wound was monitored, beginning at $0 \mathrm{~h}$ (immediately following wounding) using a Kodak MDS290 camera and software. Wound closure was quantified by measuring the distance in pixels between wound edges (10 lines per wound) at each time point, using the measuring tool in Adobe Photoshop ${ }^{\circledR}$ with a grid superimposed on the image to guide the measurements. The wound width was normalized to $100 \%$ at $0 \mathrm{~h}$ for each treatment condition and presented as a percent of wound remaining at the given time point.

\section{Immunofluorescent staining}

SKOV-3 cells were plated on glass-bottom dishes overnight, scratched with a sterile yellow pipette tip and treated with indicated concentrations of cell signaling inhibitors (Y27632, SB203580, LY294002, wortmannin and PD98059) for 6 h. Non-permeabilized cells were fixed in 1\% paraformaldehyde, then incubated with antibodies to PAI-1 (polyclonal, \#528216, Calbiochem) and uPA (monoclonal, \#394, American Diagnostica). AlexaFluorconjugated secondary antibodies (Molecular Probes, Carlsbad, CA: PAI-1, AlexaFluor 647; uPA, AlexaFluor 594) were used to visualize immunofluorescence staining with an Olympus FV500 confocal laser-scanning microscope (Microscopy Services Laboratory, Department of Pathology and Laboratory Medicine, Chapel Hill, NC). 


\section{Cell-secreted indirect uPA assay}

An indirect uPA activity assay was performed using a synthetic plasmin substrate measuring plasminogen activation by uPA as described previously [30]. Briefly, unconcentrated conditioned media from treated cells was added to buffer containing plasminogen and plasmin substrate (S-2251, Chromogenix, West Chester, OH). Triplicate samples were incubated for $60 \mathrm{~min}$ at $37^{\circ} \mathrm{C}$ and the reaction was monitored spectrophotometrically. The data presented are the average of 2 separate experiments and represents the amount of uPA activity remaining compared to the untreated SKOV-3 cells (normalized to 100\%).

\section{Western blot}

Cell lysates were harvested and protein was separated on a $10 \%$ polyacrylamide gel, transferred and blotted for active Akt (phospho-Ser 473, Cell Signaling Technology, Danvers, MA), total Akt (Cell Signaling Technology), total ERK2 (Santa Cruz, Santa Cruz, CA) or tubulin (Sigma). Conditioned media from the cells were concentrated using centrifugal filtering devices (Millipore, Billerica, MA) with a molecular weight cutoff of 30 $\mathrm{kDa}$ and treated the same as the lysates but run on either $10 \%$ or $12 \%$ gels, and blotted for PAI-1 (Molecular Innovations) and uPA (American Diagnostica). Total protein concentration was determined using a dye-binding assay (Biorad, Hercules, CA) with bovine serum albumin (BSA) as the standard. Densitometry of the Western blots was performed with ImageJ software from NIH and normalized to either Akt, ERK2, tubulin, total protein or no treatment, as indicated.

\section{Cell migration and invasion assays}

Migration experiments were conducted using BD BioCoat ${ }^{\mathrm{TM}}$ culture inserts (BD Bioscience, Bedford, MA), while invasion experiments utilized BD BioCoat ${ }^{\mathrm{TM}}$ Matrigel ${ }^{\mathrm{TM}}$ Invasion Chambers (BD Bioscience), both with an 8 - $\mu$ m diameter pore size membrane in a 24 -well companion plate, as described previously [30]. Briefly, membranes were re-hydrated with $0.1 \%$ BSA and $1 \%$ antibiotic/antimycotic in serum-free medium prior to the experiment. The chemoattractant (complete medium containing 10\% FBS) was added to the lower well of the plate. Cells were seeded onto the culture insert in serum-free medium with the given concentrations of the various cell signaling inhibitors and incubated for either 6 or $24 \mathrm{~h}$, as specified, at $37^{\circ} \mathrm{C}$. After the incubation period, the media were removed from the insert, cells on the upper surface of the membrane were removed with a cotton-tipped applicator and cells that migrated or invaded to the lower surface of the membranes were fixed with 100\% methanol. Inserts were washed with PBS, stained with Hoechst (1:20,000 in 1× PBS, Molecular Probes), and the membranes were excised from the insert, inverted and mounted on glass microscope slides. The total number of nuclei were counted in four fields at $40 \times$ magnification using UV fluorescence microscopy. The data presented are normalized to untreated SKOV-3 cells.

\section{SiRNA transfection}

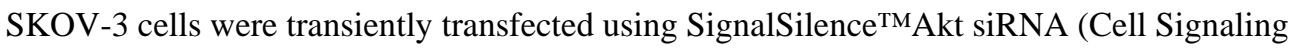
Technology) and the GeneEraser ${ }^{\mathrm{TM}}$ siRNA transfection reagent (Stratagene, LaJolla, CA), following manufacturer's guidelines. Briefly, a mixture of Opti-MEM (Gibco, Carlsbad, CA) 
and GeneEraser was incubated $15 \mathrm{~min}$ at room temperature. Then Akt siRNA (final concentration of 125 or $250 \mathrm{nM}$ ) was added and incubated for $15 \mathrm{~min}$ at room temperature. This mixture was added to SKOV-3 cells at approximately $80 \%$ confluency for $8 \mathrm{~h}$, and all siRNA experiments were performed under these same conditions. Fresh media were then added to prevent cell toxicity by the transfection reagent. Protein expression and the woundinduced migration assay were performed $48 \mathrm{~h}$ post-transfection.

\section{Akt adenovirus}

The constitutively active (myristolyated) Akt adenovirus (Myr Akt) was a generous gift from Dr. Kenneth Walsh (Boston University Medical Center, Boston, MA). SKOV-3 cells were infected with a CMV control adenovirus or Myr Akt adenovirus at an MOI 50 for $24 \mathrm{~h}$. Protein expression and wound-induced migration were measured $24 \mathrm{~h}$ post-infection.

\section{Statistical analysis}

Statistical analyses were performed using Instat (GraphPad Software, Inc, San Diego, CA). Assuming normal distribution, a one-way analysis of variance test (ANOVA) $(p<0.05)$ was used followed by a Dunnett multiple comparison test. If the $p$ value was less than 0.05 after the post-test, it was concluded that the differences observed were not due to a type I error and with a 95\% confidence interval, the difference between the means was true. In Fig. 8, a Student's $t$-test was done comparing individual treatments to SKOV-3 cells treated with vehicle (DMSO). Assuming normal distribution, $p<0.05$ was concluded to be significant and have a $95 \%$ confidence interval; that is, the differences between the means were true.

\section{Results}

\section{Effect of a selection of pharmacological inhibitors on PAI-1 and uPA expression and wound-induced migration of SKOV-3 ovarian cancer cells}

We used pharmacological inhibitors of Rho-kinase/ROCK, p38 MAPK, MEK and PI3K to better understand the signaling pathway(s) involved in regulating both PAI-1 and uPA expression and cell migration, using a wound-induced migration assay in the highly invasive SKOV-3 ovarian cancer cell line. The Rho kinase/ROCK inhibitor (Y27632) did not alter SKOV- 3 wound-induced migration (Fig. 1A and B). However, the p38 MAPK inhibitor (SB203580) and the MEK inhibitor (PD98059) reduced SKOV-3 wound-induced migration by approximately 50\% (Fig. 1A and B). The PI3K inhibitor (LY294002) reduced SKOV-3 migration by approximately $90 \%$ (Fig. 1A and B).

By immunofluorescence staining, there was an apparent increase in PAI-1 in SKOV-3 cells treated with LY294002 and PD98059, but there was no change noted in cell surface PAI-1 expression in SKOV-3 cells treated either with Y27632 or with SB203580 (Fig. 2A). Unlike that seen for PAI-1, a decrease in uPA expression was found in SKOV-3 cells treated with all of the pharmacological inhibitors (Fig. 2A).

A functional uPA activity assay was then used with conditioned media of SKOV-3 cells. This assay confirmed that all four pharmacological inhibitors altered the balance between uPA and PAI-1, reflected by the changes in functional uPA measured. Listed is the relative 
order of potency of the inhibitors on reducing uPA activity (at the highest dose tested):

Y27632<PD98059 SB203580<LY294002 (Fig. 2B).

Collectively, these results reveal that the various signaling pathways reduce wound-induced migration of SKOV-3 cells to varying extents, which is manifested by different changes with regards to both PAI-1 and uPA expression.

\section{Inhibition of PI3K increases PAI-1 expression and decreases UPA expression in SKOV-3 cells}

The PI3K pathway was examined in more detail due to the contrasting change in PAI-1 and uPA levels in SKOV-3 cells. Western blot analysis of LY294002-treated SKOV-3 cells shows a decrease in phosphorylated Akt, from $40 \%$ to $80 \%$ with increasing doses, as a measure of PI3K activity (Fig. 3). We found a substantial increase in PAI-1 secreted (2- to $>6$-fold) by SKOV-3 cells in the conditioned media upon LY294002 treatment (Fig. 3). As previously shown by others [12-14], we also found an accompanying decrease in the amount of uPA secreted (55-70\%) when SKOV-3 cells were treated with LY294002 (Fig. 3). These results imply that changes in both PAI-1 and uPA expression are a direct result of PI3K inhibition since both LY294002 and wortmannin (data not included) had similar effects.

\section{PI3K inhibitors decrease both SKOV-3 wound-induced migration and transwell invasion and migration}

The dose response of both LY294002 and wortmannin on wound-induced SKOV-3 cell migration was performed. At $12 \mathrm{~h}$, untreated SKOV-3 cells migrated into the denuded area to essentially close the wound (Fig. 4A). Increasing doses of LY294002 (5-50 $\mu \mathrm{M})$ significantly reduced SKOV-3 wound-induced migration from $20 \%$ to $80 \%$, and wortmannin $(0.25-1 \mu \mathrm{M})$ similarly affected SKOV-3 migration (Fig. 4A).

As expected, treatment with a PAI-1 blocking antibody increased the migration of LY294002-treated SKOV-3 cells compared to SKOV-3 cells treated only with LY294002 or with LY294002 and a non-specific IgG control antibody (Fig. 4B). Likewise, the uPAblocking antibody decreased SKOV-3 cell migration even further following treatment with LY294002 (Fig. 4B). These results suggest that some of the LY294002-induced migration changes are mediated by alteration in the levels, and thus the balance, of PAI-1 and uPA in SKOV-3 cells.

It is possible that the signal pathways required in cell migration over a solid surface, as in a wound-induced migration assay, may differ from those required in transwell assays. Addition of LY294002 (Fig. 5A and B) or wortmannin (Fig. 5C and D) to the SKOV-3 cells during transwell invasion and migration assays resulted in a dose-dependent decrease in both invasion and migration after $6 \mathrm{~h}$, with a maximum reduction of $80 \%$. The experiments were carried out for $6 \mathrm{~h}$, to ensure that any changes measured were not the result of loss in cell viability induced by the compounds. This would also allow for direct comparison with uPA and PAI-1 expression after $6 \mathrm{~h}$ of treatment (Fig. 2A). These results suggest that the effect of PI3K inhibitors was similar to the wound-induced migration assay with SKOV-3 
cells; thus, inhibition of PI3K/Akt reduces cell invasion and migration by altering the existing levels of PAI-1 and uPA to change the PAI-1:uPA ratio.

\section{Modulation of Akt alters SKOV-3 wound migration, PAI-1 expression and uPA expression}

We used siRNA to specifically down-regulate Akt and then re-assessed wound-induced migration and levels of Akt, PAI-1 and uPA expression in the SKOV-3 cells. Transient transfection of SKOV-3 cells with Akt siRNA reduces total Akt expression by $30 \%$ when compared to SKOV-3 cells transfected with GeneEraser ${ }^{\mathrm{TM}}$ transfection reagent alone. As a result, there was a dose-dependent up-regulation of PAI-1 (>200\%) and a downregulation of uPA expression (60-75\%) (Fig. 6A). Despite the incomplete siRNA silencing of Akt expression, the change in uPA and PAI-1 levels was similar to that in SKOV-3 cells following LY294002 treatment (compare to $25 \mu$ M LY294002 in Fig. 3). Furthermore, transient transfection of the SKOV-3 cells with Akt siRNA has a dose-dependent reduction (50-70\%) in wound closure compared to SKOV-3 cells in the presence of the transfection reagent alone (Fig. 6B). Again, the reduction in migration by Akt siRNA is similar to that seen when SKOV-3 cells are treated with LY294002 (compare to $10 \mu$ M LY294002 in Fig. 4). These results further support an association between PI3K/Akt and PAI-1 and uPA expression to influence cell migration in SKOV-3 cells.

We then utilized a constitutively active Akt construct (Myr Akt) to further define the relationship of active Akt, PAI-1 and uPA expression and wound-induced migration in SKOV-3 cells. Greater than two-fold increased levels of Akt in SKOV-3 cells infected with the Myr Akt adenovirus correlated with a greater than 50\% decrease in PAI-1 expression (Fig. 7A). The change in uPA expression is minor compared with our results when Akt was down-regulated by siRNA; however, the balance between inhibitor and protease is still shifted, and in this case, in favor of uPA. In addition to changes in protein expression, Myr Akt significantly increased wound-induced migration of SKOV-3 cells, from $30 \%$ to $4 \%$ wound remaining (Fig. 7B). These results help to further establish the link between the plasminogen activator system as components in the PI3K/Akt signaling pathway regulating cell migration and invasion.

\section{IGF-1 and insulin modulate SKOV-3 wound migration and UPA/PAI-1 expression}

Given the established link between IGF-1 and insulin with the PI3K/Akt pathway in many cell systems [23,31], we next examined the influence of these growth factors on uPA and PAI-1 levels and their ability to modulate SKOV-3 cell migration. Urokinase expression in SKOV-3 cells was increased by insulin and IGF-1 with a concomitant decrease in PAI-1 (Fig. 8A). Under serum-free conditions, the addition of LY294002 alone revealed a similar pattern of increased PAI-1 levels described earlier (Fig. 8A). The addition of IGF-1 with LY294002, but not the combination of insulin with LY294002, also showed the trend to increase PAI-1 expression (Fig. 8A). The effects of IGF-1 and insulin on the activity of PI3K, with or without LY294002, were confirmed by Western blot analysis of phosphorylated Akt (data not shown). Insulin and IGF-1 significantly increased the woundinduced migration of SKOV-3 cells (from $70 \%$ to $20 \%$ and $40 \%$ wound remaining, respectively), while LY294002 eliminated this enhanced cell migration (Fig. 8B). These results imply that insulin and IGF-1 alter the balance between uPA and PAI-1 in favor of 
uPA, thus enhancing cell migration. LY294002 attenuates this promigratory activity, which further supports an association between PI3K/Akt and PAI-1:uPA levels as an influence on SKOV-3 cell migration.

\section{Discussion}

There is a need to develop new approaches in chemoprevention, early detection and innovative treatments for ovarian cancer, the leading cause of gynecological cancer deaths. Defining the genetic aberrations and their underlying molecular changes can help in the development of new detection methods and treatments for ovarian cancers. Increased expression of PAI-1 and UPA in ovarian cancers suggests that they are markers linked to a poor prognosis [4-8]. Therefore, it is imperative to understand the regulation of PAI-1 and uPA expression through signal pathways involved in migration and invasion of cancer cells that contribute to the progression and mortality of ovarian cancer.

The PI3K pathway is involved in many cellular processes, including proliferation, survival, apoptosis, migration, invasion and cytoskeletal rearrangements. The results presented in this paper dissect the importance of this pathway, using pharmacological inhibitors, targeted deletion or deliberate over-expression of active Akt in SKOV-3 ovarian cancer cell migration and invasion with respect to regulation of PAI-1 and uPA expression. The balance between PAI-1 and uPA expression is delicate, but extremely important in regulating cell behavior. A shift in the balance towards PAI-1, whether due to an increase in PAI-1, a decrease in uPA or a combination of both, tends to prevent in vitro migration and invasion of cancer cells, as we and others have shown previously [30,32-35]. Likewise, downregulation of PAI-1, up-regulation of uPA or both would shift the balance in favor of uPA and presumably increase in vitro migration and invasion. This concept helps to explain our results using a survey of pharmacological inhibitors to signaling pathways known to affect cell migration. No matter the change in PAI-1 expression, the inhibitors of Rho kinase/ ROCK, p38 MAPK, MEK and PI3K all decrease uPA expression in SKOV-3 ovarian cancer cells, effectively shifting the PAI-1:uPA balance in favor of PAI-1. Only the p38 MAPK, MEK and PI3K inhibitors decrease wound-induced SKOV-3 cell migration. The lack of effect of the Rho kinase/ROCK inhibitor may be due to only a small decrease in uPA expression. Collectively, our results support the finding that various signaling pathways positively and negatively alter both PAI- 1 and UPA expression to profoundly regulate SKOV-3 cell wound-induced migration.

Through our experiments, a new link emerges between PAI-1 expression and levels of phosphorylated Akt, which alters both cell migration and cell invasion. SKOV-3 cells treated with LY294002 showed a dose-dependent decrease in phosphorylated Akt, a dosedependent increase in PAI-1 and a dosedependent decrease in UPA. Inhibition of PI3K activity also resulted in a dose-dependent decrease in cell migration and invasion in a transwell assay, and a dose-dependent decrease in migration measured in a wound-induced migration assay. Likewise, specific down-regulation of Akt by siRNA resulted in an increase in PAI-1 expression, a decrease in uPA expression and a decrease in woundinduced migration. By contrast, expression of constitutively active Akt caused the opposite effects on SKOV-3 cells: an increase in phosphorylated Akt levels correlated with a 
decrease in PAI-1 expression and an increase in wound-induced migration. The changes in SKOV-3 cell migration that accompanied the increase (constitutively active Akt adenovirus) or decrease (LY294002 and wortmannin treatment, Akt siRNA) in active Akt levels were similar to previously published studies [11-15,36-41]. It will be important to further these observations using different ovarian cancer cell lines, especially those that are not dependent on PI3K/Akt for migration and invasion. However, in further support of our results, a recent study showed a correlation between decreased phosphorylated Akt levels and decreased invasion in SKOV-3 cells [42]. Likewise, the regulation of uPA expression and activity by the PI3K/Akt pathway that we showed confirmed previously published results [12$15,39,40]$. Finally, Venugopal et al. [23] showed in an in vivo study that plasma PAI-1 was up-regulated in Akt-deficient mice (protein kinase $\mathrm{B}$ or $\mathrm{PKBa}^{--}$), which would attenuate the PI3K/Akt signaling pathway.

Potential initiators of the PI3K/Akt pathway that could alter the plasminogen activator system are insulin and IGF-1. Elevated levels of IGF-1 have been associated with an increased risk in development of ovarian cancer [43,44]. The relationship of insulin is of importance since obesity and metabolic syndrome have been linked to various cancers [45]. Recently, it was shown that insulin-induced PAI-1 levels in 3T3L1 adipocytes were increased by treatment with the PI3K inhibitor LY294002 [23]. Using IGF-1 and insulin, which are both known to increase uPA levels, in a wound-induced migration assay, we found that these growth factors increased SKOV-3 cell migration and this increase was attenuated upon treatment with LY294002. Our results are supported by work showing that IGF-1 affects invasion and proliferation in ovarian and cervical cancer cells through activation of Akt and ERK1/2 [29], resulting in an increase in uPA activity in ovarian cancer [46]. Overall, the novel finding here is that PI3K/Akt activity alters cell migration due to changes in both PAI-1 and uPA expression in SKOV-3 cells, indicating that the PI3K/Akt signaling pathway negatively regulates PAI-1 expression while it up-regulates UPA expression, and this action is further modulated by IGF-1 and insulin.

The "traditional" function of PAI-1 is to inhibit uPA and thus prevent plasmin generation and matrix degradation. However, the "non-traditional" functions for PAI-1, including cell adhesion, proliferation, angiogenesis, apoptosis and cell signaling, are likely contributing to the detrimental role played by PAI- 1 and why this inhibitor is associated with a grim prognosis in many cancers (reviewed in $[47,48]$ and references cited therein). Based on the experimental end-points that we measured, the decrease in SKOV-3 migration and invasion implies a more favorable scenario to prevent further metastasis. However, since it is well established that increased levels of PAI-1 are associated with a poor prognosis in ovarian cancer [4-8], this apparent contradiction seen here might be better understood by evoking a combination of both traditional and the nontraditional functions of PAI-1. Increased levels of PAI-1, in conjunction with inhibition of the PI3K pathway, would guard the primary tumor mass from host fibrinolytic proteases, effectively decrease localized cell migrationinvasion by inhibition of tumor plasminogen activator capability, promote neovascularization and help to maintain an anti-apoptotic environment in order to allow for genetic changes toward a metastatic phenotype. As the tumor begins to over-express PI3K/ Akt, the PAI-1:uPA balance changes to now favor uPA and influence tumor invasion and 
metastasis. Thus, our results expand the relationship between PAI-1 and uPA that is regulated by PI3K/Akt in the highly invasive SKOV-3 ovarian cancer cell line.

\section{Acknowledgments}

Stipend support to B.R.W. and J.C.C. was provided by NIEHS 5T32-ES-07017 from the National Institute of Environmental Health Sciences, while stipend support for L.M.B. was through the Integrative Vascular Biology Program (T32 HL69768 from the National Institutes of Health) and the Susan G. Komen Breast Cancer Foundation (BCTR0503475). This research was supported in part by Research Grants HL-06350 and HL-32656 (to F.C.C.) from the National Institutes of Health. We are grateful to Dr. Tom Hilder and Dr. Lee Graves (Department of Pharmacology, UNC-CH School of Medicine) for the use of reagents and for providing their experimental advice. We also thank Dr. Kenneth Walsh (Boston University Medical Center, Boston, MA) for providing the Myr Akt adenovirus.

\section{References}

1. Jemal A, Siegel R, Ward E, Murray T, Xu J, Smigal C, et al. Cancer statistics, 2006. CA Cancer J Clin. 2006; 56(2):106-130. [PubMed: 16514137]

2. Brewer MA, Johnson K, Follen M, Gershenson D, Bast R Jr. Prevention of ovarian cancer: intraepithelial neoplasia. Clin Cancer Res. 2003; 9(1):20-30. [PubMed: 12538447]

3. Stack MS, Ellerbroek SM, Fishman DA. The role of proteolytic enzymes in the pathology of epithelial ovarian carcinoma. Int J Oncol. 1998; 12(3):569-576. [PubMed: 9472094]

4. Borgfeldt C, Hansson SR, Gustavsson B, Masback A, Casslen B. Dedifferentiation of serous ovarian cancer from cystic to solid tumors is associated with increased expression of mRNA for urokinase plasminogen activator (uPA), its receptor (uPAR) and its inhibitor (PAI-1). Int J Cancer. 2001; 92(4):497-502. [PubMed: 11304683]

5. Konecny G, Untch M, Pihan A, Kimmig R, Gropp M, Stieber P, et al. Association of urokinase-type plasminogen activator and its inhibitor with disease progression and prognosis in ovarian cancer. Clin Cancer Res. 2001; 7(6):1743-1749. [PubMed: 11410515]

6. Kuhn W, Pache L, Schmalfeldt B, Dettmar P, Schmitt M, Janicke F, et al. Urokinase (uPA) and PAI-1 predict survival in advanced ovarian cancer patients (FIGO III) after radical surgery and platinum-based chemotherapy. Gynecol Oncol. 1994; 55(3 Pt 1):401-409. [PubMed: 7835780]

7. van der Burg M, Henzen-Logmans S, Berns E, van Putten W, Klijn J, Foekens J. Expression of urokinase-type plasminogen activator (uPA) and its inhibitor PAI-1 in benign, borderline, malignant primary and metastatic ovarian tumors. Int J Cancer. 1996; 69(6):475-479. [PubMed: 8980250]

8. Kuhn W, Schmalfeldt B, Reuning U, Pache L, Berger U, Ulm K, et al. Prognostic significance of urokinase (uPA) and its inhibitor PAI-1 for survival in advanced ovarian carcinoma stage FIGO IIIc. Br J Cancer. 1999; 79(11-12):1746-1751. [PubMed: 10206287]

9. Keely PJ, Westwick JK, Whitehead IP, Der CJ, Parise LV. Cdc42 and Rac1 induce integrinmediated cell motility and invasiveness through PI(3)K. Nature. 1997; 390(6660):632-636. [PubMed: 9403696]

10. Tanno S, Mitsuuchi Y, Altomare DA, Xiao GH, Testa JR. AKT activation up-regulates insulin-like growth factor I receptor expression and promotes invasiveness of human pancreatic cancer cells. Cancer Res. 2001; 61(2):589-593. [PubMed: 11212254]

11. Kotelevets L, Noe V, Bruyneel E, Myssiakine E, Chastre E, Mareel M, et al. Inhibition by plateletactivating factor of Src- and hepatocyte growth factor-dependent invasiveness of intestinal and kidney epithelial cells. Phosphatidylinositol 3'-kinase is a critical mediator of tumor invasion. J Biol Chem. 1998; 273(23):14138-14145. [PubMed: 9603913]

12. Tanaka Y, Kobayashi H, Suzuki M, Kanayama N, Terao T. Transforming growth factor-beta1dependent urokinase up-regulation and promotion of invasion are involved in Src-MAPKdependent signaling in human ovarian cancer cells. J Biol Chem. 2004; 279(10):8567-8576. [PubMed: 14676209]

13. Sliva D, Rizzo MT, English D. Phosphatidylinositol 3-kinase and NF-kappaB regulate motility of invasive MDA-MB-231 human breast cancer cells by the secretion of urokinase-type plasminogen activator. J Biol Chem. 2002; 277(5):3150-3157. [PubMed: 11689575] 
14. Mahabeleshwar GH, Kundu GC. Syk, a protein-tyrosine kinase, suppresses the cell motility and nuclear factor kappa B-mediated secretion of urokinase type plasminogen activator by inhibiting the phosphatidylinositol 3'-kinase activity in breast cancer cells. J Biol Chem. 2003; 278(8):62096221. [PubMed: 12477728]

15. Kusch A, Tkachuk S, Haller H, Dietz R, Gulba DC, Lipp M, et al. Urokinase stimulates human vascular smooth muscle cell migration via a phosphatidylinositol 3-kinase-Tyk2 interaction. J Biol Chem. 2000; 275(50):39466-39473. [PubMed: 10995743]

16. Sturge J, Hamelin J, Jones GE. N-WASP activation by a beta1-integrin-dependent mechanism supports PI3K-independent chemotaxis stimulated by urokinase-type plasminogen activator. J Cell Sci. 2002; 115(Pt 4):699-711. [PubMed: 11865026]

17. Kiian I, Tkachuk N, Haller H, Dumler I. Urokinase-induced migration of human vascular smooth muscle cells requires coupling of the small GTPases RhoA and Rac1 to the Tyk2/PI3-K signalling pathway. Thromb Haemostasis. 2003; 89(5):904-914. [PubMed: 12719789]

18. Chandrasekar N, Mohanam S, Gujrati M, Olivero WC, Dinh DH, Rao JS. Downregulation of uPA inhibits migration and PI3k/Akt signaling in glioblastoma cells. Oncogene. 2003; 22(3):392-400. [PubMed: 12545160]

19. Kietzmann T, Jungermann K, Gorlach A. Regulation of the hypoxiadependent plasminogen activator inhibitor 1 expression by MAP kinases. Thromb Haemostasis. 2003; 89(4):666-673. [PubMed: 12669121]

20. Takahashi H, Uno S, Watanabe Y, Arakawa K, Nakagawa S. Expression of nerve growth factorinduced type 1 plasminogen activator inhibitor (PAI-1) mRNA is inhibited by genistein and wortmannin. NeuroReport. 2000; 11(5):1111-1115. [PubMed: 10790891]

21. Ploplis VA, Balsara R, Sandoval-Cooper MJ, Yin ZJ, Batten J, Modi N, et al. Enhanced in vitro proliferation of aortic endothelial cells from plasminogen activator inhibitor-1-deficient mice. J Biol Chem. 2004; 279(7):6143-6151. [PubMed: 14625301]

22. Dunn SE, Torres JV, Oh JS, Cykert DM, Barrett JC. Up-regulation of urokinase-type plasminogen activator by insulin-like growth factor-I depends upon phosphatidylinositol-3 kinase and mitogenactivated protein kinase kinase. Cancer Res. 2001; 61(4):1367-1374. [PubMed: 11245436]

23. Venugopal J, Hanashiro K, Yang ZZ, Nagamine Y. Identification and modulation of a caveolaedependent signal pathway that regulates plasminogen activator inhibitor-1 in insulin-resistant adipocytes. Proc Natl Acad Sci U S A. 2004; 101(49):17120-17125. [PubMed: 15569940]

24. Fresno Vara JA, Casado E, de Castro J, Cejas P, Belda-Iniesta C, Gonzalez-Baron M. PI3K/Akt signalling pathway and cancer. Cancer Treat Rev. 2004; 30(2):193-204. [PubMed: 15023437]

25. Bellacosa A, de Feo D, Godwin AK, Bell DW, Cheng JQ, Altomare DA, et al. Molecular alterations of the AKT2 oncogene in ovarian and breast carcinomas. Int J Cancer. 1995; 64(4): 280-285. [PubMed: 7657393]

26. Cheng JQ, Godwin AK, Bellacosa A, Taguchi T, Franke TF, Hamilton TC, et al. AKT2, a putative oncogene encoding a member of a subfamily of protein-serine/threonine kinases, is amplified in human ovarian carcinomas. Proc Natl Acad Sci U S A. 1992; 89(19):9267-9271. [PubMed: 1409633]

27. Shayesteh L, Lu Y, Kuo WL, Baldocchi R, Godfrey T, Collins C, et al. PIK3CA is implicated as an oncogene in ovarian cancer. Nat Genet. 1999; 21(1):99-102. [PubMed: 9916799]

28. Yuan ZQ, Sun M, Feldman RI, Wang G, Ma X, Jiang C, et al. Frequent activation of AKT2 and induction of apoptosis by inhibition of phosphoinositide-3-OH kinase/Akt pathway in human ovarian cancer. Oncogene. 2000; 19(19):2324-2330. [PubMed: 10822383]

29. Shen MR, Lin AC, Hsu YM, Chang TJ, Tang MJ, Alper SL, et al. Insulin-like growth factor 1 stimulates $\mathrm{KCl}$ cotransport, which is necessary for invasion and proliferation of cervical cancer and ovarian cancer cells. J Biol Chem. 2004; 279(38):40017-40025. [PubMed: 15262997]

30. Whitley BR, Palmieri D, Twerdi CD, Church FC. Expression of active plasminogen activator inhibitor-1 reduces cell migration and invasion in breast and gynecological cancer cells. Exp Cell Res. 2004; 296(2):151-162. [PubMed: 15149846]

31. Abid MR, Guo S, Minami T, Spokes KC, Ueki K, Skurk C, et al. Vascular endothelial growth factor activates PI3K/Akt/forkhead signaling in endothelial cells. Arterioscler Thromb Vasc Biol. 2004; 24(2):294-300. [PubMed: 14656735] 
32. Degryse B, Sier CF, Resnati M, Conese M, Blasi F. PAI-1 inhibits urokinase-induced chemotaxis by internalizing the urokinase receptor. FEBS Lett. 2001; 505(2):249-254. [PubMed: 11566185]

33. Hjortland GO, Bjornland K, Pettersen S, Garman-Vik SS, Emilsen E, Nesland JM, et al. Modulation of glioma cell invasion and motility by adenoviral gene transfer of PAI-1. Clin Exp Metastasis. 2003; 20(4):301-309. [PubMed: 12856717]

34. Kjoller L, Kanse SM, Kirkegaard T, Rodenburg KW, Ronne E, Goodman SL, et al. Plasminogen activator inhibitor-1 represses integrin- and vitronectin-mediated cell migration independently of its function as an inhibitor of plasminogen activation. Exp Cell Res. 1997; 232(2):420-429. [PubMed: 9168821]

35. Praus M, Collen D, Gerard RD. Both u-PA inhibition and vitronectin binding by plasminogen activator inhibitor 1 regulate HT1080 fibrosarcoma cell metastasis. Int J Cancer. 2002; 102(6): 584-591. [PubMed: 12447999]

36. Ellerbroek SM, Halbleib JM, Benavidez M, Warmka JK, Wattenberg EV, Stack MS, et al. Phosphatidylinositol 3-kinase activity in epidermal growth factor-stimulated matrix metalloproteinase-9 production and cell surface association. Cancer Res. 2001; 61(5):1855-1861. [PubMed: 11280738]

37. Imai Y, Clemmons DR. Roles of phosphatidylinositol 3-kinase and mitogen-activated protein kinase pathways in stimulation of vascular smooth muscle cell migration and deoxyriboncleic acid synthesis by insulin-like growth factor-I. Endocrinology. 1999; 140(9):4228-4235. [PubMed: 10465296]

38. Reiske HR, Kao SC, Cary LA, Guan JL, Lai JF, Chen HC. Requirement of phosphatidylinositol 3kinase in focal adhesion kinase-promoted cell migration. J Biol Chem. 1999; 274(18):1236112366. [PubMed: 10212207]

39. Kobayashi H, Suzuki M, Kanayama N, Terao T. Genetic down-regulation of phosphoinositide 3kinase by bikunin correlates with suppression of invasion and metastasis in human ovarian cancer HRA cells. J Biol Chem. 2004; 279(8):6371-6379. [PubMed: 14597629]

40. Das R, Mahabeleshwar GH, Kundu GC. Osteopontin stimulates cell motility and nuclear factor kappaB-mediated secretion of urokinase type plasminogen activator through phosphatidylinositol 3-kinase/Akt signaling pathways in breast cancer cells. J Biol Chem. 2003; 278(31):28593-28606. [PubMed: 12771144]

41. Arboleda MJ, Lyons JF, Kabbinavar FF, Bray MR, Snow BE, Ayala R, et al. Overexpression of AKT2/protein kinase Bbeta leads to upregulation of beta1 integrins, increased invasion, and metastasis of human breast and ovarian cancer cells. Cancer Res. 2003; 63(1):196-206. [PubMed: 12517798]

42. Sumigama S, Ito T, Kajiyama H, Shibata K, Tamakoshi K, Kikkawa F, et al. Suppression of invasion and peritoneal carcinomatosis of ovarian cancer cells by overexpression of AP-2alpha. Oncogene. 2004

43. Hirano S, Ito N, Takahashi S, Tamaya T. Clinical implications of insulin-like growth factors through the presence of their binding proteins and receptors expressed in gynecological cancers. Eur J Gynaecol Oncol. 2004; 25(2):187-191. [PubMed: 15032278]

44. Lukanova A, Lundin E, Toniolo P, Micheli A, Akhmedkhanov A, Rinaldi S, et al. Circulating levels of insulin-like growth factor-I and risk of ovarian cancer. Int J Cancer. 2002; 101(6):549554. [PubMed: 12237896]

45. Boyd DB. Insulin and cancer. Integr Cancer Ther. 2003; 2(4):315-329. [PubMed: 14713323]

46. Tanaka Y, Kobayashi H, Suzuki M, Hirashima Y, Kanayama N, Terao T. Genetic downregulation of pregnancy-associated plasma protein-A (PAPP-A) by bikunin reduces IGF-I-dependent Akt and ERK1/2 activation and subsequently reduces ovarian cancer cell growth, invasion and metastasis. Int J Cancer. 2004; 109(3):336-347. [PubMed: 14961570]

47. Andreasen PA, Egelund R, Petersen HH. The plasminogen activation system in tumor growth, invasion, and metastasis. Cell Mol Life Sci. 2000; 57:25-40. [PubMed: 10949579]

48. Stefansson S, Lawrence DA. Old dogs and new tricks: proteases, inhibitors, and cell migration. Sci STKE. 2003; 2003(189):pe24. [PubMed: 12837933] 
A)

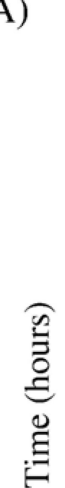

B)

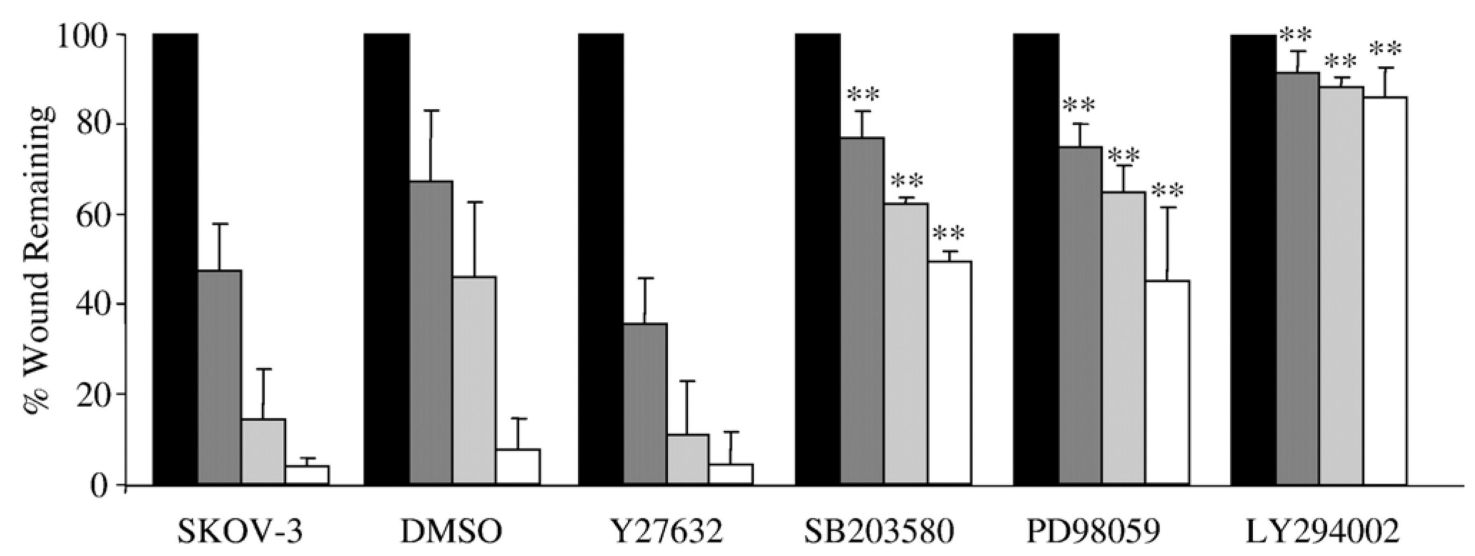

Fig. 1.

Rho kinase/ROCK, p38 MAPK, MEK and PI3K inhibitors differentially alter woundinduced SKOV-3 cell migration. (A) A wound-induced migration assay was performed on SKOV-3 cells in the absence and presence of DMSO vehicle control, $10 \mu \mathrm{M}$ Y27632, $10 \mu \mathrm{M}$ SB203580, $25 \mu \mathrm{M}$ PD98059 or $25 \mu \mathrm{M}$ LY294002. Photomicrographs of the treated cells are shown for the initial wounding $(0 \mathrm{~h})$ and at 6,12 and $24 \mathrm{~h}$ post-wounding. (B) The distance the cells migrated into the wounded area was quantified as described in Materials and methods and presented as the percent wound remaining at the given times. $* * p<0.01$, compared with untreated SKOV-3 cells at the given time point, $0 \mathrm{~h}$ (black bar), $6 \mathrm{~h}$ (dark grey bar), $12 \mathrm{~h}$ (light grey bar) and $24 \mathrm{~h}$ (white bar). 
A)
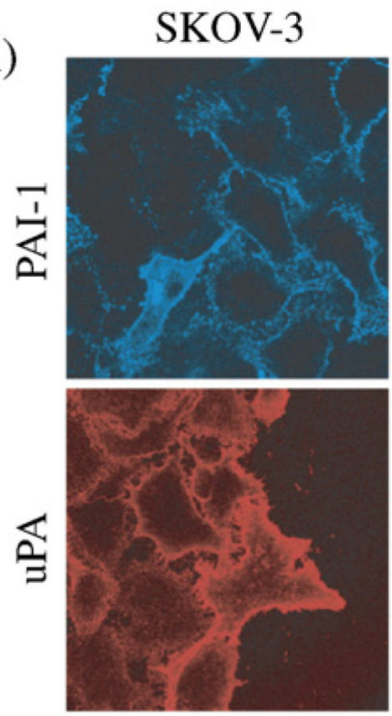

Y27632
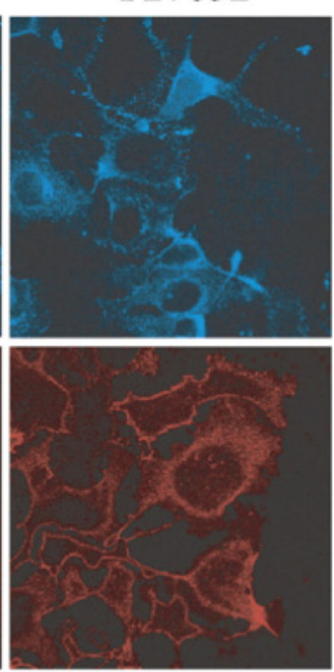

SB203580
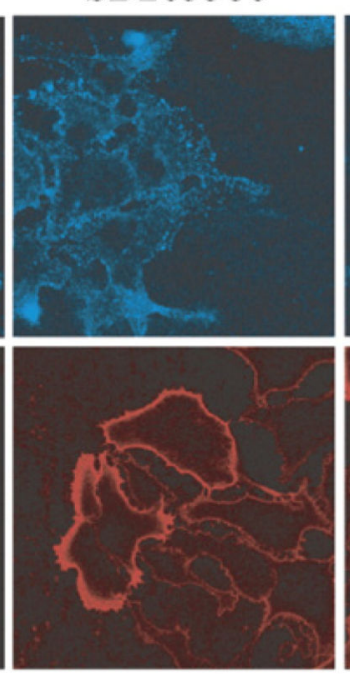

PD98059
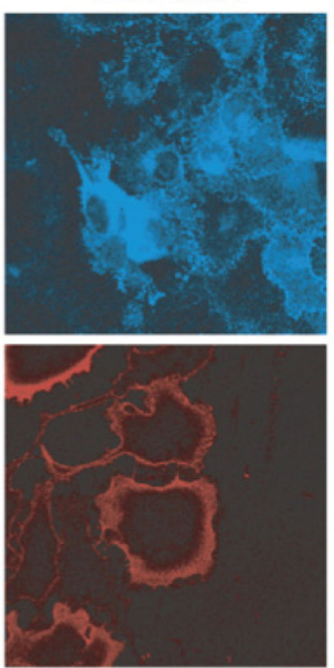

LY294002
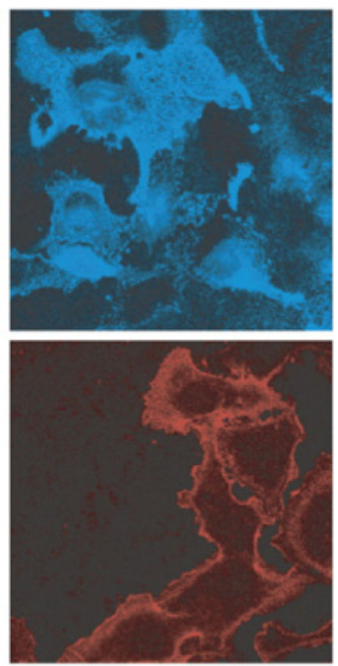

B)

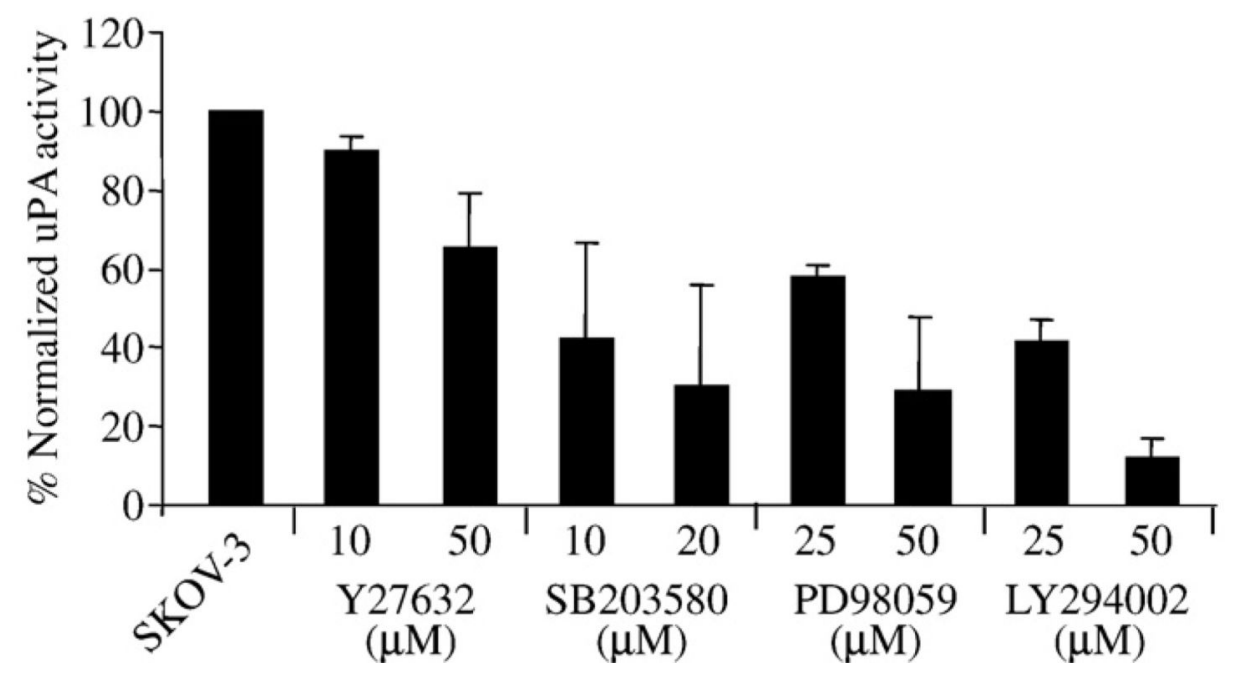

Fig. 2.

Rho kinase/ROCK, p38 MAPK, MEK and PI3K inhibitors differentially alter the expression of PAI-1 compared to uPA in SKOV-3 cells. (A) SKOV-3 cells were wounded and treated with $10 \mu \mathrm{M}$ Y27632, $20 \mu \mathrm{M}$ SB203580, $25 \mu \mathrm{M}$ PD98059 or $25 \mu \mathrm{M}$ LY294002 for $6 \mathrm{~h}$, then the cell surface expression of PAI-1 and UPA was detected with immunofluorescence staining of non-permeabilized cells. (B) SKOV-3 cells were treated with the given concentrations of the same panel of cell signaling inhibitors for $24 \mathrm{~h}$ before uPA activity in the conditioned media was measured. uPA activity was normalized to the untreated SKOV-3 cells (results are given as mean values of triplicate assays done in two separate experiments). 
A)

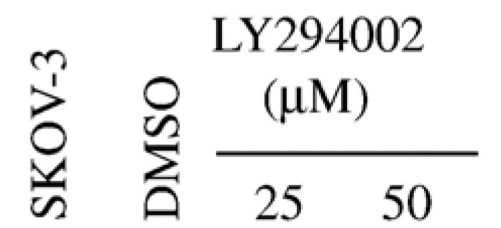

pAkt (Ser 473)

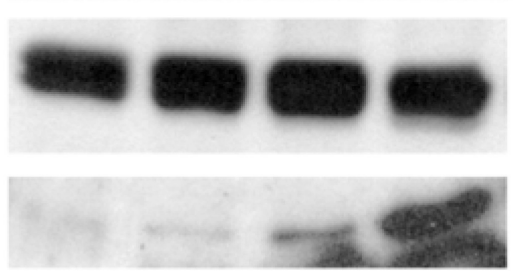

\author{
Total Akt
}

PAI-1

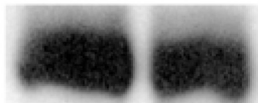

uPA

B)

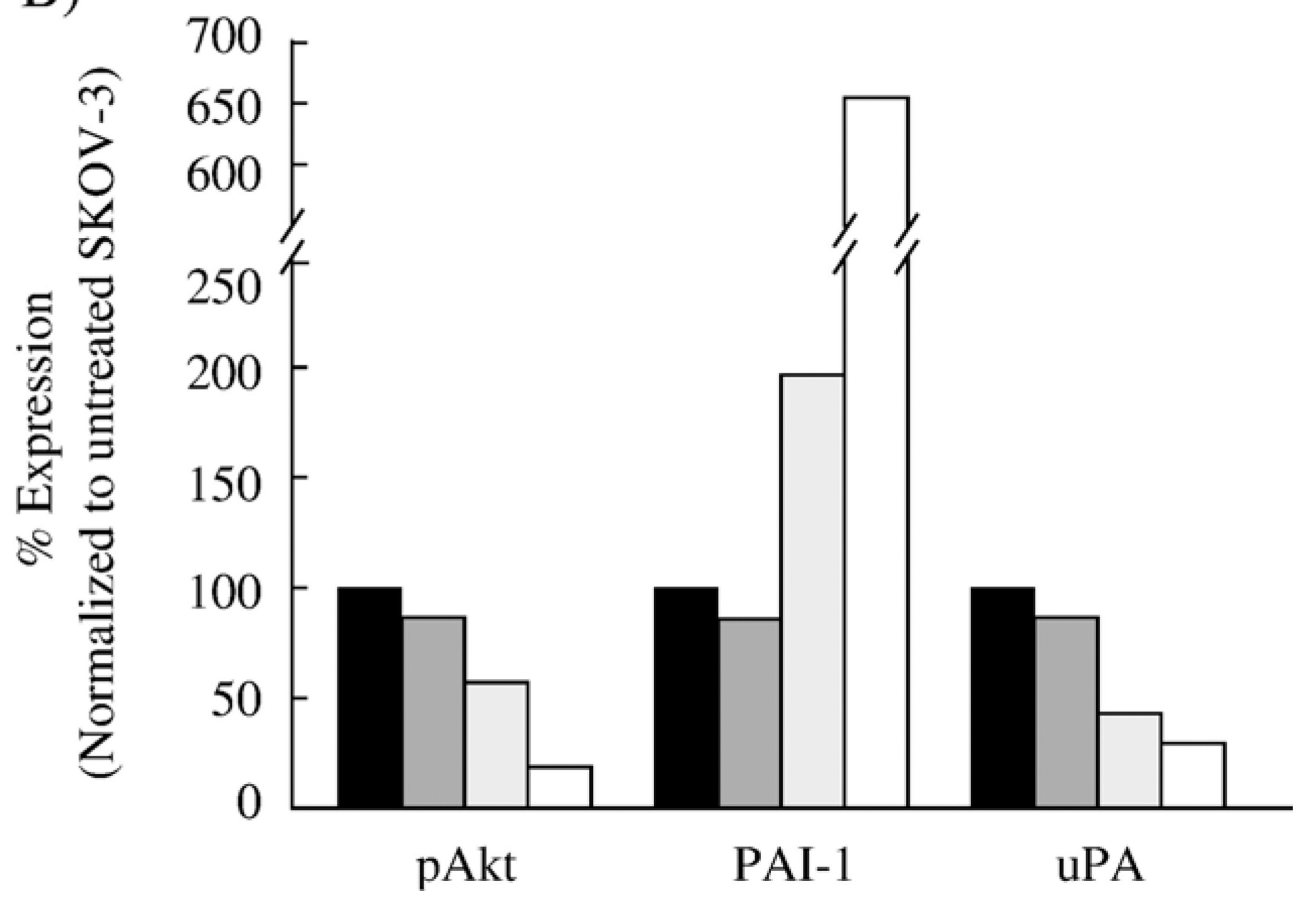

Fig. 3.

Inhibition of PI3K increases PAI-1 expression and decreases uPA expression in SKOV-3 cells. SKOV-3 cells were treated for $24 \mathrm{~h}$ in serum-free media with two doses of the PI3K inhibitor, LY294002. (A) Lysates were harvested and equal protein was separated on a 10\% polyacrylamide gel, transferred and blotted for active Akt (phospho-Ser473) and total Akt. Conditioned media from the cells were concentrated and treated the same as the lysates, except blotted for PAI-1 and uPA, loaded by total protein. (B) The bands detected byWestern blot were quantitated by densitometry as described in Materials and methods as 
SKOV-3 cells untreated (black bar), DMSO-treated control SKOV-3 cells (dark grey bar), $25 \mu \mathrm{M}$ LY294002 (light grey bar) and $50 \mu \mathrm{M}$ LY294002 (white bar). 


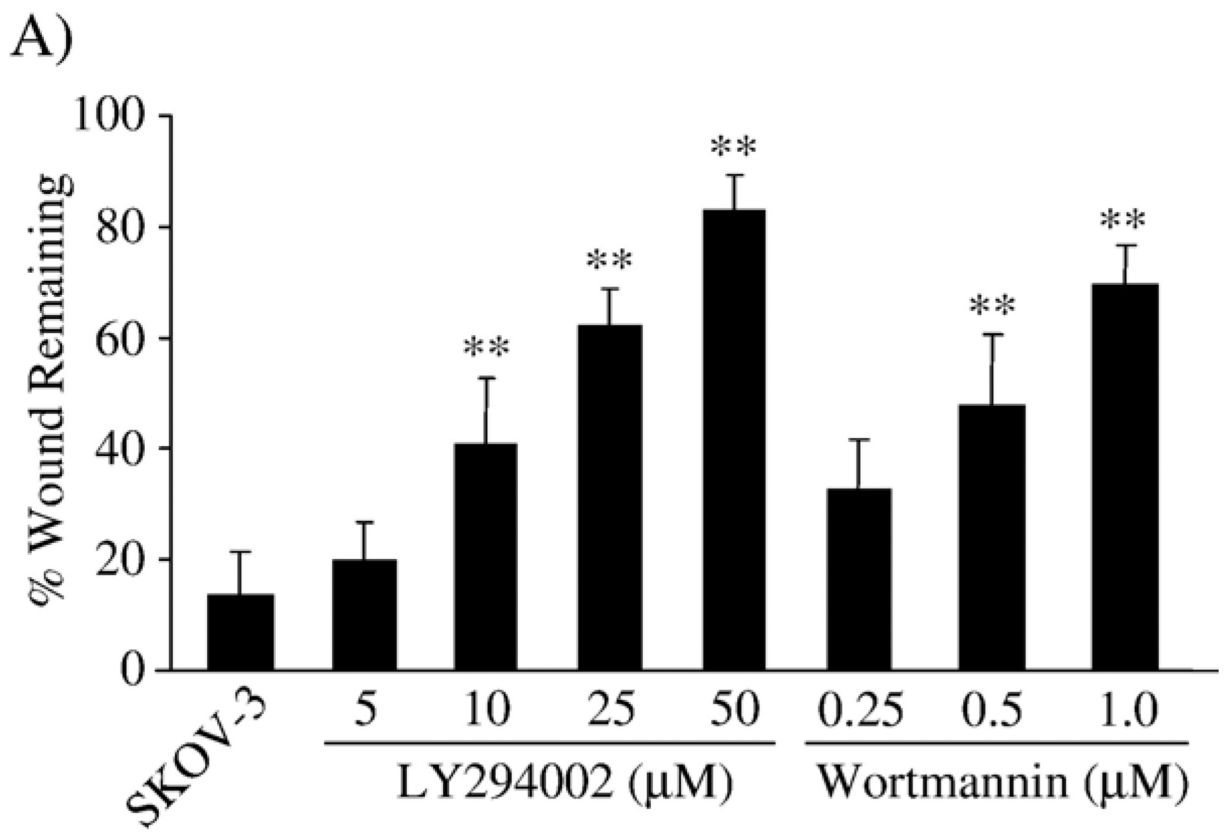

B)

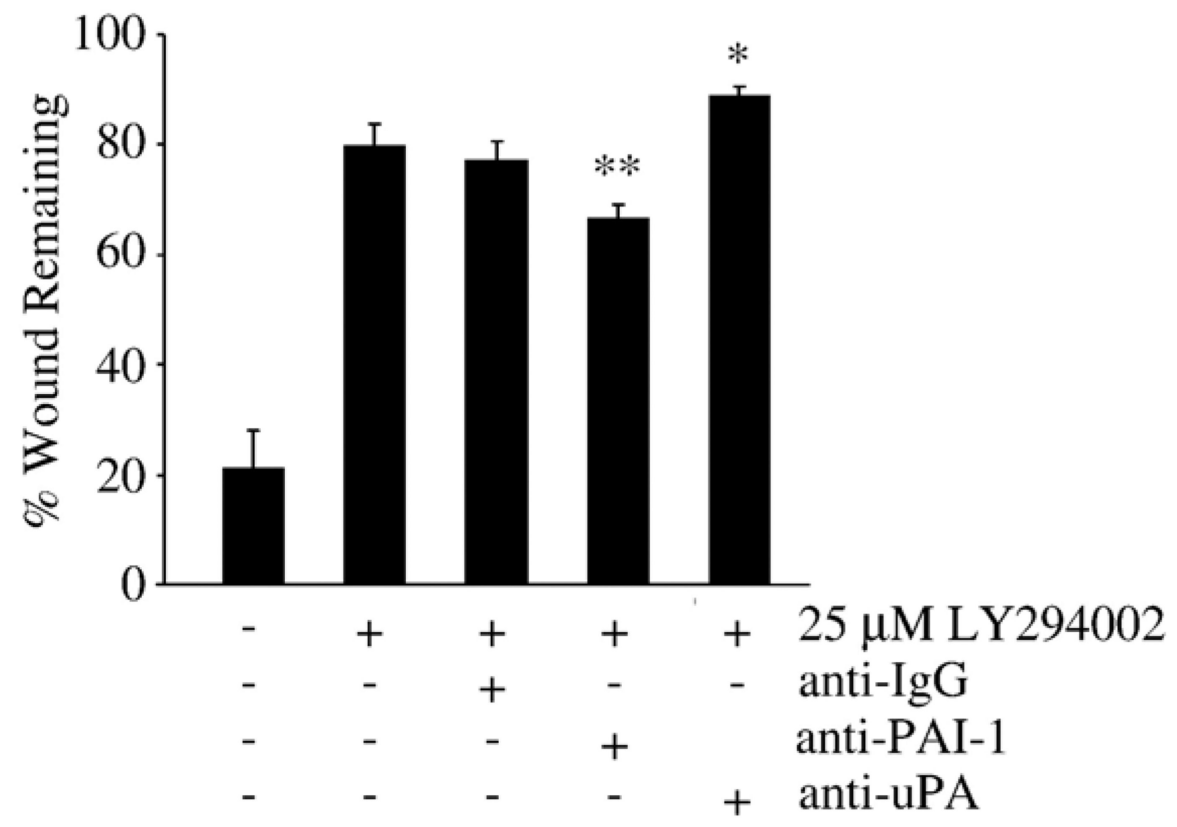

Fig. 4.

Inhibition of PI3K, PAI-1 and UPA alter SKOV-3 wound-induced migration. (A) Woundinduced migration in the presence of increasing doses of LY294002 or wortmannin was measured for $12 \mathrm{~h}$. $* p<0.05,{ }^{* *} p<0.01$ compared with untreated SKOV-3 cells. (B) Woundinduced migration in the presence of $25 \mu \mathrm{M}$ LY294002 and uPA- and PAI-1-blocking antibodies (each at $20 \mu \mathrm{g} / \mathrm{ml}$ ) for $12 \mathrm{~h}$. The graphs represent the average of 2-4 separate experiments performed in triplicate. ${ }^{*} p<0.05, * * p<0.01$ compared with SKOV-3 cells treated with $25 \mu \mathrm{M}$ LY294002. 
A)

C)
B)
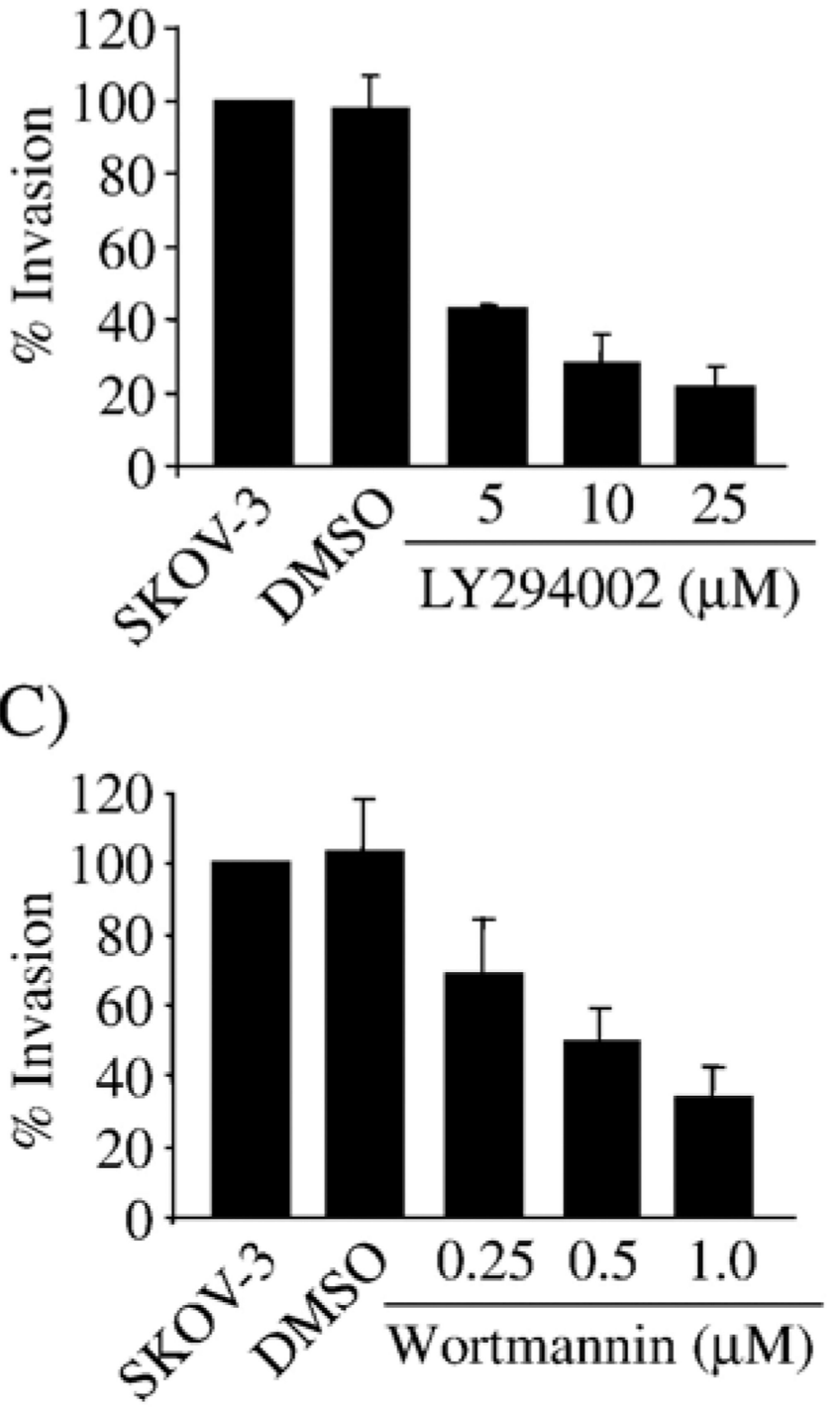

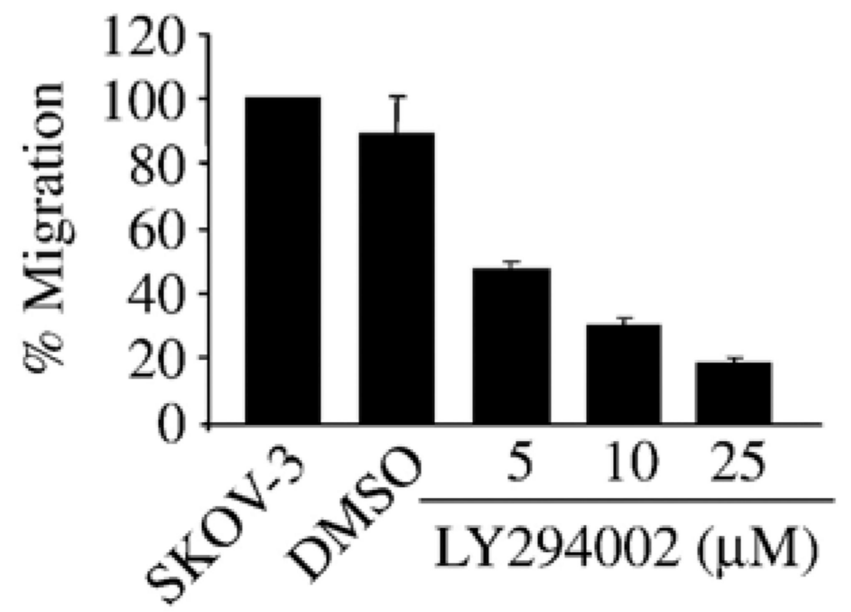

D)

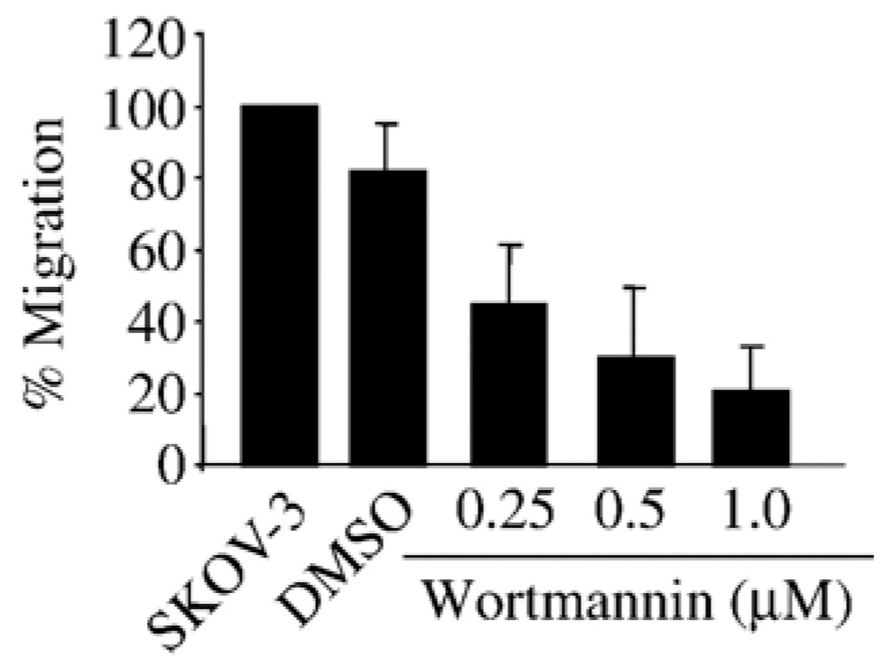

Fig. 5.

Inhibition of PI3K decreases SKOV-3 invasion and migration. SKOV-3 transwell invasion and migration were measured in the presence of increasing doses of LY294002 (A and B) or wortmannin $(\mathrm{C}$ and $\mathrm{D})$ for $6 \mathrm{~h}$. Cell migration and invasion assays were performed as described in Materials and methods. Graphs presented are the average of 2 experiments performed in duplicate. 

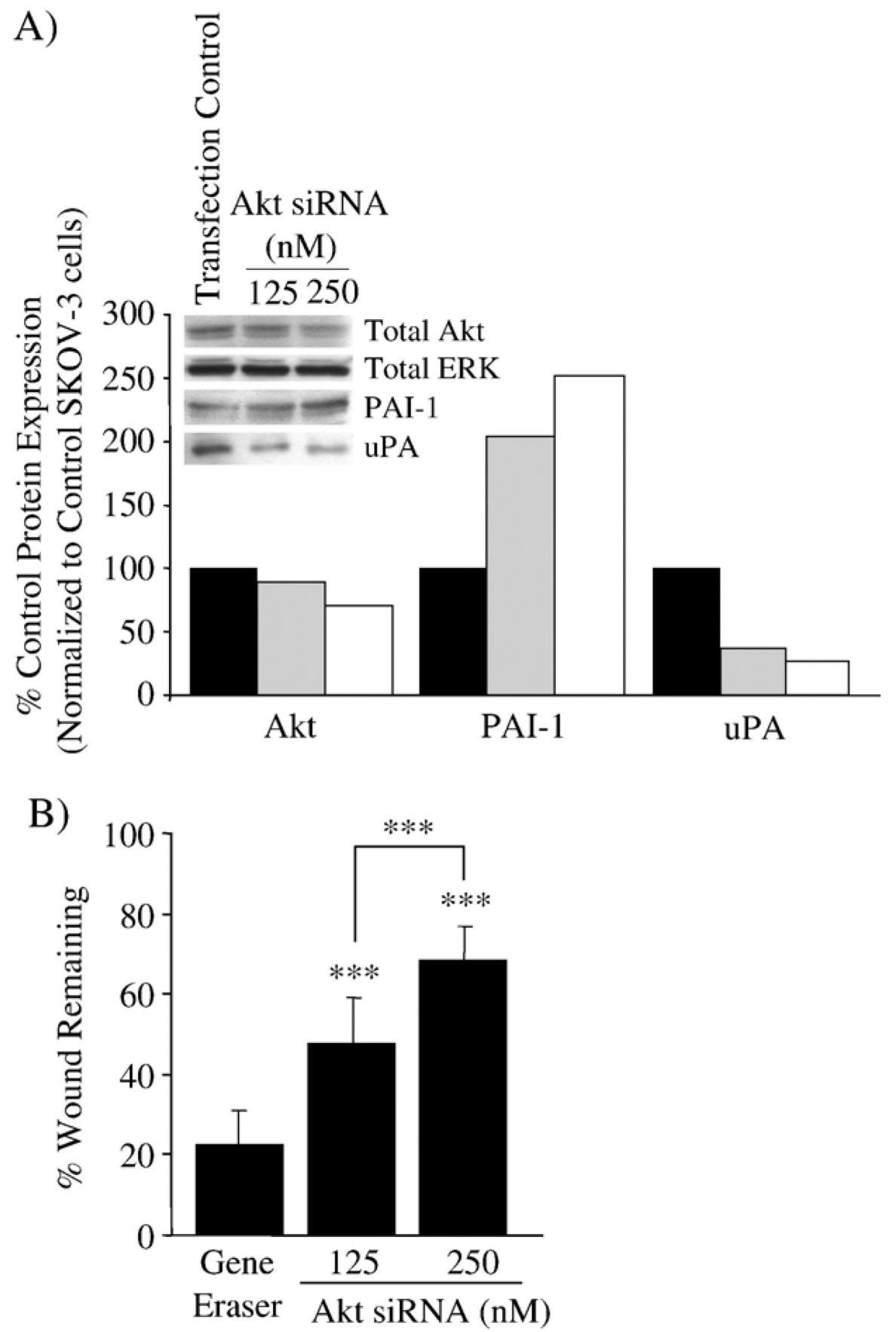

Fig. 6.

Modulation of Akt in SKOV-3 cells affects PAI-1 and uPA expression and cell migration. SKOV-3 cells were transiently transfected with Akt siRNA. Total Akt, ERK2, PAI-1 and UPA protein expression were monitored in cells transfected with GeneEraser transfection reagent alone or with Akt siRNA (125 nM or $250 \mathrm{nM}$ ). (A) Total Akt, total ERK, PAI-1 and UPA expression were monitored and densitometry was used to quantify the change in protein expression detected by Western blot, normalized to ERK2 as a total protein loading control, and presented as the percent expression compared to GeneEraser transfection control 
SKOV-3 cells. SKOV-3 cells with GeneEraser transfection reagent alone (black bar); SKOV-3 cells with GeneEraser plus $125 \mathrm{nM}$ Akt siRNA (grey bar); SKOV-3 cells with GeneEraser plus $250 \mathrm{nM}$ Akt siRNA (white bar). (B) The ability of Akt siRNA-transfected SKOV-3 cells to migrate was monitored in a wound-induced migration assay in $1 \%$ FBS conditions, and the results are presented as the percent wound remaining at $12 \mathrm{~h}$. *** $p<0.001$ compared with SKOV-3 cells with GeneEraser alone, or between Akt siRNA concentrations. 


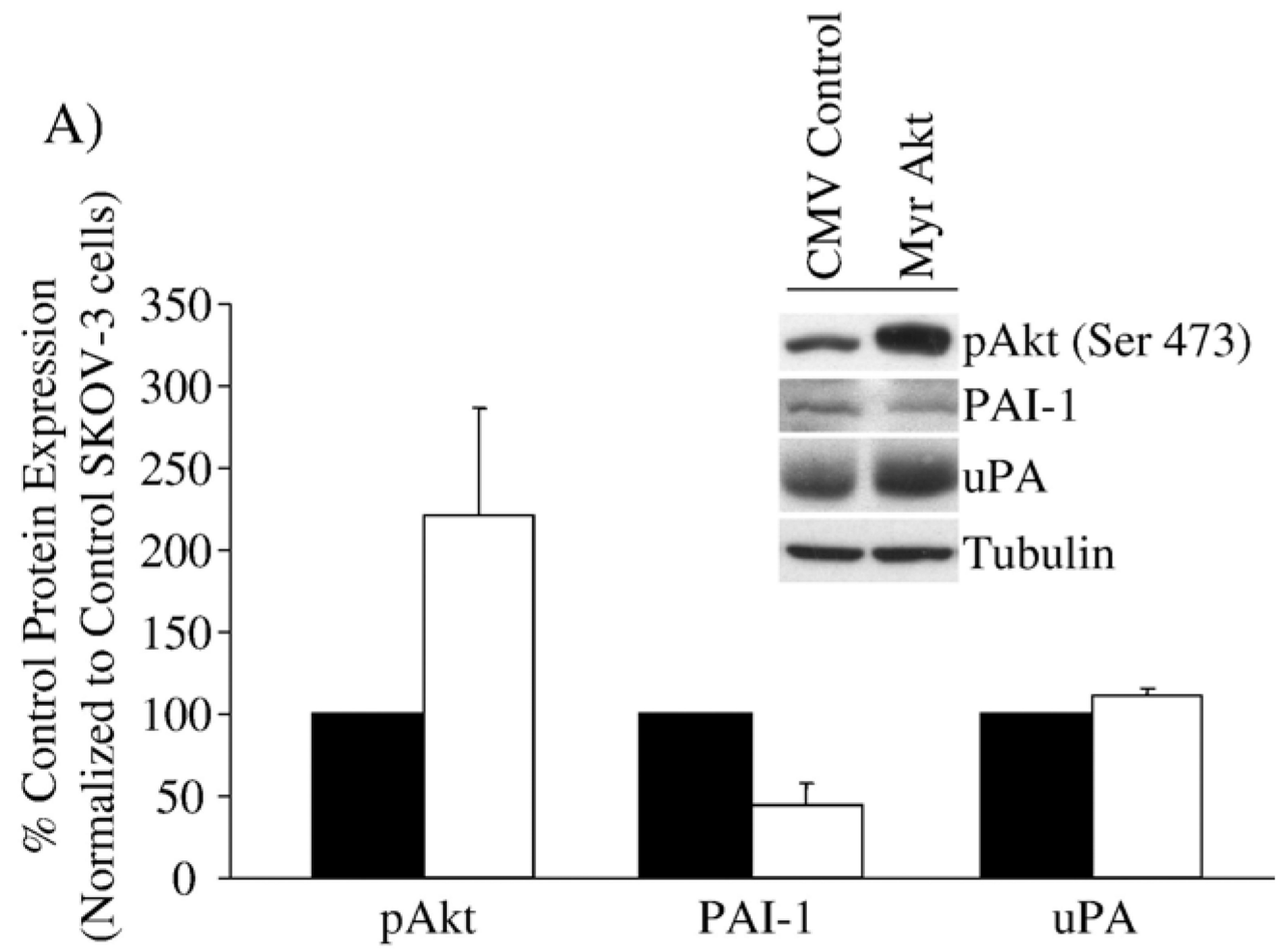

B)

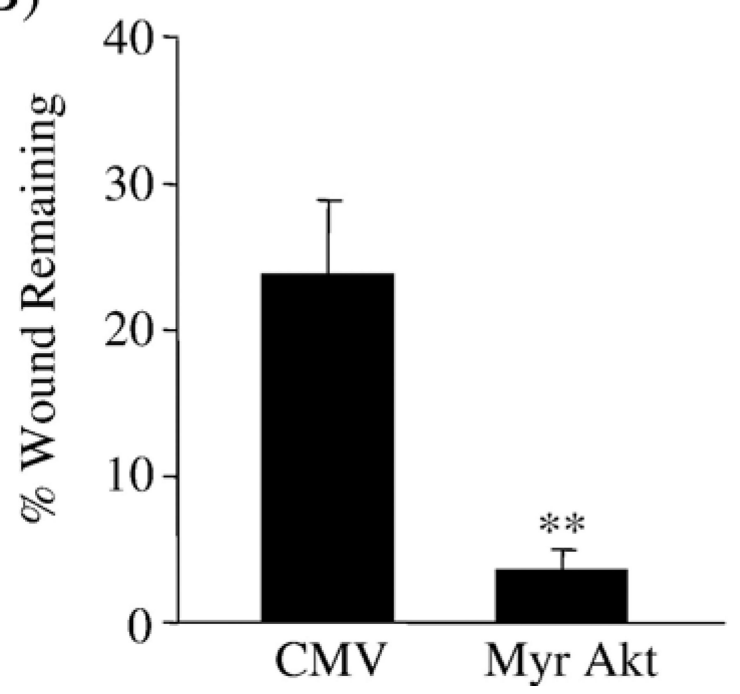

Fig. 7.

Over-expression of Akt in SKOV-3 cells affects PAI-1 expression and cell migration. SKOV-3 cells were infected with control CMV or Myr Akt adenovirus at MOI 50. (A) Active Akt (pAkt), PAI-1 and uPA expression were monitored, and densitometry used to quantify the change in protein expression detected by Western blot, normalized to tubulin as a protein loading control; the results are presented as the percent expression compared to control CMV adenovirus-treated SKOV-3 cells. Results are presented as the percent expression of Myr Akt-infected SKOV-3 cells (white bar) compared to CMV control 
adenovirus-infected SKOV-3 cells (black bar). (B) The effect of Myr Akt expression on SKOV-3 cell migration was measured in a wound-induced migration assay in $1 \%$ FBS conditions, and the results are presented as the percent wound remaining at $12 \mathrm{~h} . * * p<0.01$ compared with SKOV-3 cells with control CMV alone. 
A)

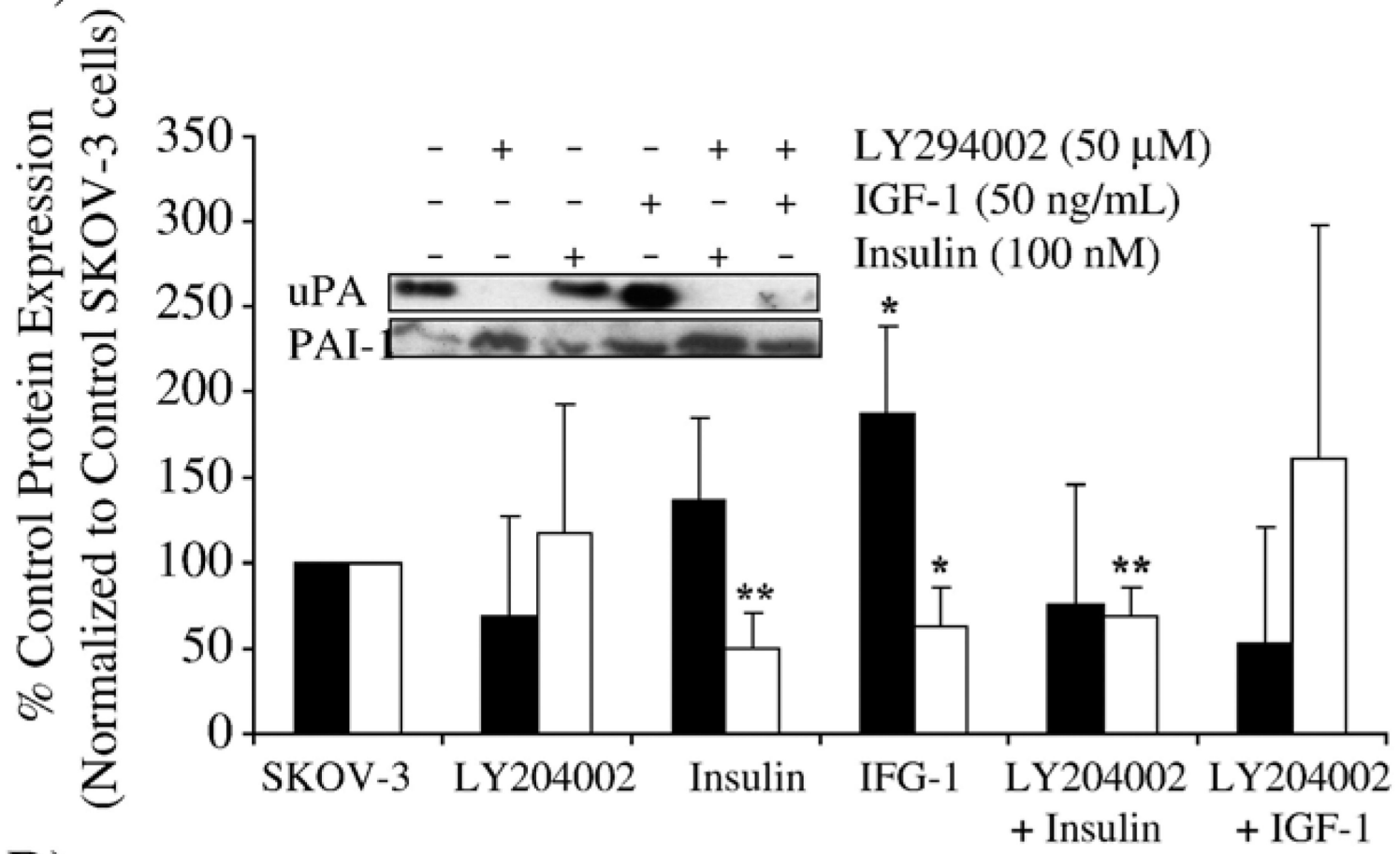

B)

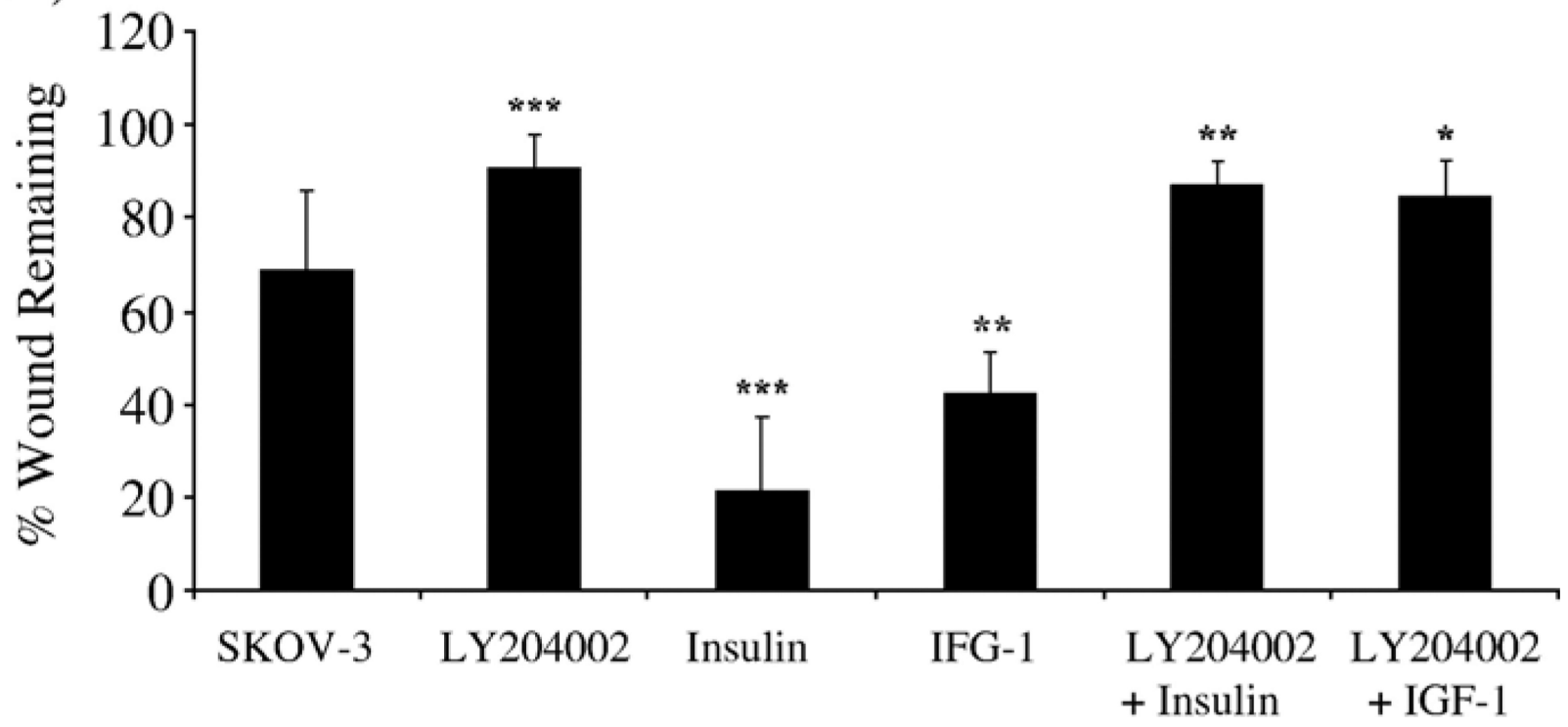

Fig. 8.

IFG-1 and insulin enhance cell migration and alter the balance between uPA and PAI-1 in SKOV-3 cells. SKOV-3 cells were treated with LY294002 and insulin (100 nM) or IGF-1 (50 ng/ml) as described in Materials and methods. (A) PAI-1 and uPA expression (secreted in the conditioned media) were monitored, and densitometry used to quantify the change in protein expression detected by Western blot (UPA, black bar; PAI-1, white bar); data were presented as the percent expression compared to control-treated SKOV-3 cells. ${ }^{*} p<0.05$ or $* * p<0.01$ for UPA or PAI-1 compared with untreated SKOV-3 cells for each respective 
protein. (B) The effect of insulin and IGF-1 in combination with LY294002 was measured in a wound-induced migration assay under serum-free conditions, and results are presented as the percent wound remaining at $12 \mathrm{~h} .{ }^{*} p<0.05, * * p<0.01$ or $* * * p<0.001$ compared with untreated SKOV-3 cells. 